From Shakespeare to Modern Ages

\title{
Gender Relations in Tawfiq alHakim' The Tree Climber from a feminist perspective
}

\author{
إعداد الباحثة:

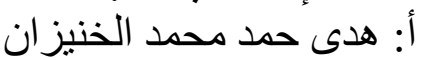 \\ Huda Hamad Muhammad Al_Khenizan \\ محاضر بقسم اللغة الإنجليزية كلية حريماء للعلوم والدر اسات الإنسانية_ جامعة \\ شقر اء بالمملكة العربية السعودية. \\ halKhenizan@su.ed.sa \\ إثر اف: أ.د. محمد أحمد مصطفي الليثي. \\ أستاذ مشارك بكلية اللغات و الترجمة جامعة الإمام محمد بن سعود الإسلامية. \\ Abstract
}

This chapter is aimed to provide an in-depth analysis of gender relations in Tawfiq al-Hakim's 1962 play, The Tree Climber (Ya Talee' Es-Shagara) through the feminist perspective, specifically through the writings and thoughts of Simone de Beauvoir. Al-Hakim is a prominent figure in Theatre of the Mind or Intellectual Theatre, which deals with abstract ideas, such as the struggle between man and time as described in Ahl al-Kahf (The Sleepers in the Cave), 1933 or between man and space as in Shahrazad, 1934. The play The Tree Climber is considered one of his master pieces since it reflects the influence of the Theatre of the Absurd during his stay in France. The play is governed as much by an obsession with the unreal as the obsession with a distinct representation of gender relations that have developed across different social, economic, and cultural levels.

The play revolves around the disappearance of Bahana, a childless widow, who has married for the second time. She is obsessed with the baby girl she aborted during her first marriage almost forty years ago. Her present husband Bahadir is a sixty-five-year-old retired man who is obsessed with the only orange tree in the yard of his small house and the green lizard that lives under the tree, Lady Green. In the story, Lady Green is suspected of killing Bahana, but she reappears. The husband bombards his wife with questions. She responds with "no" to every question even when "no" does not logically apply. The husband becomes frustrated. He chokes Bahana and she dies.

This singular focus will highlight the scope of al-Hakim's capability to articulate gender relations that engages the audience in array of actions that highlight a myriad of different social, economic and cultural criteria in which Beauvoir s examination of women's lives and their inherent limitations is paralleled in al-Hakim's play. Beauvoir's ethical interest in relational principles, such as female's 


\section{Dahlia Kashmiry, PhD}

otherness, the social institution of marriage, the issue of abortion, the focus on the question of old age, and domestic violence are vocalized in al-Hakim's exposition and treatment of gender relations in his play The Tree Climber.

\section{Introduction}

Over years, women are known as the core of the world. Women had been facing oppression, violence and discrimination throughout history that lasts recently. The study indicates that there are many factors of oppression, domination and inequalities over women, as for instance: social, cultural, marital, patriarchal, etc. as being part of ruled-society by men. The domination over women is a common trait of developing countries not developed ones, as intellectual and cultural development does not create sense of degradation or move societies backward. Islam forbids oppression and persecution of women, but seeks for elevating and glorifying women's status in any era. The study aims at identifying problems and obstacles related to gender that women witness during past decades. The researcher focuses primarily on Tawfiq Al-Hakim's The Tree Climber and to what extent Al-Hakim managed to portray female characters.

Tawfiq Al-Hakim (1898-1987) is an outstanding writer in Egypt (AlSharadgeh, 2019). He is one of great Egyptian writers, as Taha Hussein, Abbas Al-Aqqad, etc. that are considered the co-founders of modern Egyptian literature (AlSharadgeh, 2019). The study adopts feminist perspective in Tawfiq Al-Hakim's The Tree Climber, in relation to absurdity in life (AlSharadgeh, 2019). Al-Hakim wrote The Tree Climber influenced by theatre of Absurd, during his visit to France (AlSharadgeh, 2019). One of key reasons made Al-Hakim to embrace new movement of literature, that is absurd theatre, is differences in Eastern and Western cultures (AlSharadgeh, 2019).

\section{- Research Questions:}

In order to implement previous research objectives, the study attempts to answer numerous questions, most important are the following:

1) How are oppression, underestimation and discrimination over women symbolized within literature works of art?

2) How does Tawfiq Al-Hakim The Tree Climber represent women in society?

3) How had women been characterized throughout history as being oppressed and dependent? 
From Shakespeare to Modern Ages

4) To what extent does Al-Hakim succeed in portraying the sufferings and hardships of female characters? And in what ways is this depiction true and authentic in real life?

5) How feminist perspective in Tawfiq Al-Hakim's The Tree Climber does related to Simone De Beauvoir's own thoughts and visions?

6) How do preoccupations in life and misunderstanding between married couples result in violence and oppression over women that may cause murdering women?

7) How did theatre of Absurd affect Tawfiq Al-Hakim's style of writing in general and specifically his work of art The Tree Climber?

\section{Gender Relations in Tawfiq al-Hakim's The Tree Climber}

This chapter provides an in-depth analysis of gender relations in Tawfiq al-Hakim's 1962 play, The Tree Climber (Ya Talee' EsShagara) through the feminist perspective, specifically through the writings and thoughts of Simone de Beauvoir. The play is a watershed event that introduces the concept of the irrational and absurd to Egyptian theater. It depicts a diversity of themes and techniques, ranging from social realism to intellectual formation in addition to experimentation with the theater of the absurd inspired during alHakim's stay in France. As a matter of convenience, al-Hakim's major plays are classified thematically into different categories. His early experimentation with drama includes plays, such as al-Khuruj min alJanna (Expulsion from Paradise, 1928), that address the comedy of manners and themes from society. A variation on the social theme of the conflict between tradition and modernity is surely one of the major themes of his dramatic contributions, one of which is alRajul alladhi Samad (The Man who Withstood the Current), 1950. Moreover, alHakim is a prominent figure in Theatre of the Mind or Intellectual Theatre, which deals with abstract ideas, such as the struggle between man and time as described in Ahl al-Kahf (The Sleepers in the Cave), 1933 or between man and space as in Shahrazad, 1934. A number of al-Hakim's plays describe strikingly absurdist notions, suggesting that al-Hakim was presumably in tune with the western literary movement, predominantly the Theater of the Absurd. According to The Oxford Guide to Literature in English Translation, al-Hakim's The Tree Climber is "the first play by al-Hakim to show the influence of the Theatre of the Absurd" (155). The play is governed as much by an 


\section{Dahlia Kashmiry, PhD}

obsession with the unreal as the obsession with a distinct representation of gender relations that have developed historically and thus, the play is highly significant. In this account, al-Hakim's play, The Tree Climber, which is composed of two acts, is arguably the seedbed for so many of his later plays that pay specific attention to gender roles. The play revolves around the disappearance of Bahana, a childless widow, who has married for the second time. She is obsessed with the baby girl she aborted during her first marriage almost forty years ago. Her present husband Bahadir is a sixty-five-year-old retired man who is obsessed with the only orange tree in the yard of his small house and the green lizard that lives under the tree, Lady Green. In the story, Lady Green is suspected of killing Bahana, but she reappears. The husband bombards his wife with questions. She responds with "no" to every question even when "no" does not logically apply. The husband becomes frustrated. He chokes Bahana and she dies.

De Beauvoir's examination of the female's otherness, the social institution of marriage, the issue of abortion, the concept of bad faith, the focus on the question of old age, and domestic violence are paralleled in al-Hakim's exposition and treatment of gender relations in his play The Tree Climber. De Beauvoir's ethical interest in relational principles, such as otherness and marriage with all its permutations, are strongly emphasized to verify al-Hakim's representation of gender relations in the The Tree Climber. The seriousness of al-Hakim's desire to construct gender roles based on the concept of female otherness can be seen through the masterful use of the two animal symbols: (1) the lizard and (2) the cow.

From the very beginning of the play, Bahana is associated with Lady Green, a lizard that resides under the tree:

DETECTIVE: "When exactly did your mistress disappear?"

MAID: "Just as the lizard returned to its lair."

DETECTIVE: "You mean at sunset?"

MAID: "I didn't see the sun set."

DETECTIVE: "And when does the lizard return to its lair?"

MAID: "When my master makes his appearance from under the tree" (from al Hakim 88; act 1).

The association of the lizard with the wife shows a clear tendency to celebrate and embrace the notion of female otherness. Al-Hakim's willingness to explore Bahana's otherness through the lizard symbol specifically relates to de Beauvoir's ensuing existential concepts of female otherness as she asserts in the introduction to The Second Sex: "the category of Other is as original as consciousness itself" (de 


\section{From Shakespeare to Modern Ages}

Beauvoir 27) and that throughout history a woman "determines and differentiates herself in relation to man, and he does not in relation to her; she is the inessential in front of the essential. He is the Subject; he is the Absolute. She is the Other" (de Beauvoir 26).

The lizard is an ominous symbol of the deformed goddess Isis, the most important goddess of Orient Egypt. Isis is the goddess of love, marriage, fertility, and she is the deity who establishes love between a man and woman in addition to between children and their parents (Smith 25). The lizard symbol represents the goddess Isis based on the idea: "The goddess is also famed for her devotion to her husband, Osiris. When Osiris is killed and dismembered by the evil god Seth, Isis gathers up the pieces, and eventually her devotion is able to resuscitate Osiris" (Smith 25). In al-Hakim's construction of the lizard as a symbol for the goddess Isis, there is a tendency to establish the paradigm of proper wifely behavior in a patriarchal society. Nawal El Saadawi, a feminist, and advocate of women's rights, who is sometimes described as "the Simone de Beauvoir of the Arab world" (Nawal El Saadawi | Egyptian Physician, Psychiatrist, Author), argues:

"The goddess Isis has not been given her due as a woman who represented justice and truth but has been, instead, portrayed as the ideal faithful wife whose only mission was to resurrect her murdered husband, Osiris. In our ancient Egyptian history, the goddess Isis has a wider horizon. However, al-Hakim's limited perspective of the woman prevents him from viewing Isis's prominent personality with its different dimensions. Isis is the goddess of wisdom, knowledge, and rapid mobility. She is the goddess who discovered the agricultural skills and taught the Egyptian farming and baking" (Youkhanna 62).

Thus, al-Hakim's depiction of Bahana as a lizard, the symbol of Isis, protection, fertilization, serving the tree, and the symbol of Osiris and man in general (Fontaine 261) corresponds to de Beauvoir's examination of marriage as a social institution based on imposing the woman as "a service rendered to the husband" (de Beauvoir 503).

The close connection between the lizard and the wife throughout the play symbolizes the wife's uncertainty and mystery and adds a touch of otherness. For example, at various moments in the play, the wife's and lizard's inseparable relationship is so obvious that they become one and the same. Both the wife and lizard are associated with the green color as a reference to vegetation, camouflage techniques of 


\section{Dahlia Kashmiry, PhD}

deception and disappearance, and the constant life changes (Hamudi 255). In Act One, the maid informs the detective, "This same lizard. That's what he calls her. I've never seen her, but he sees her every day" (al-Hakim 90; act 1) to show that Bahadir's close emotional attachment to the lizard works in parallel with his marital relationship with the wife.

Throughout the play, the wife's disappearance and reappearance, which constitute the driving force of the action, coordinate with those of the lizard to create the sensation of the otherness. For example, when Bahadir returns from prison to find that his wife has returned and is safe, he goes to the garden to discover the return of his lizard. He cries out joyfully, "Yes, Lady Green has returned. I spotted her ambling along in her green dress on her way to her sanctuary ... . I wonder where she could have been?" (al-Hakim 142; act 2). This same question links the wife with the lizard as Bahadir immediately remembers his wife's three-day absence and confronts her: "Talking of which - where were you?" (al-Hakim 142; act 2). Similarly, the death scene at the end of Act Two is a final emphasis of their inseparable relationship, which emphasizes their single entity. Bahadir's announcement of the disappearance of his wife's corpse at the climactic moment of the play is immediately followed by his announcement that the lizard is lying dead in the same hole designated for his wife's burial.

Al-Hakim's description of the lizard in relation to the female character Behana continues much longer in Bahadir's endless admiration of Lady Green's beauty: "I always find her beautiful with her little body attired in perpetual greenness and that extraordinary brightness in her brilliant eyes" (al-Hakim 94; act 1) as he represents the female identity as a passive entity. The lizard is not a person; she is a mere nonhuman figure. Even further illuminating the female's passivity and objectification, Bahadir also uses passive verbs to describe things being done to Lady Green. He describes her as "attired" in a green dress, while "the tree is denuded of its green leaves, she remains radiant in her greenness as she goes down to her sanctuary at the foot of the tree" (al-Hakim 94; act 1).

Clearly, in Bahadir's eyes, the components that make up the beautiful and perfect Lady Green are completely performative and are based in fashion, function, and physical appearance. Simone de Beauvoir strongly affirms, "One is not born a woman, but rather becomes one" (15). The process of "becoming", is described by de Beauvoir as a constant process; women are always continually 
From Shakespeare to Modern Ages

performing the actions they observe around them, and so the becoming is essentially a perpetual rehearsal. The becoming means that there are cultural expectations and norms that make up a gender that is, the metaphorical "performance cues" that are placed upon an assigned sexed body. Thus, women grow up watching the other women around them mimicking performances, and they consequently imitate the performance themselves. Judith Butler's Gender Trouble proposed the groundbreaking theory of gender as constant performance: a series of cues observed, internalized, and repeated over time (Butler 45). Interestingly, all of Lady Green's defining characteristics are described as acts with multiple performative female characteristics, thus constructing a perfect feminine model.

Within the core of the little Bahadir's song, "Oh tree climber bring me a cow with you/Oh cow climber bring me a tree with you" (alHakim 109; act 1), and the detective's song, "Oh tree climber bring me a cow with you/Milk it and feed me with a china spoon" (alHakim 112; act 1), the female's role in patriarchal society is depicted as an absolute service. The notion of the sacred cow in the song can be traced back as far as the ancient predynastic Egyptian cults (al-Adly 42). The goddess Hathor is defined in Bleeker's book Hathor and Thoth: Two Key Figures of the Ancient Egyptian Religion as "a cow wearing the headgear. Egyptologists often call Hathor as a mother goddess who is renowned as the patroness of love, as bestower of the blessing of children, as the goddess who promotes fertility in general" (29).

The use of the phrase "Chinese spoon" in this instance suggests a metaphor for excessive kindness, caring, and attention. Scrutinizing the male's imagination of the cow provides a plausible depiction of a subjugated woman, one who has been implicitly complicit in her own exploitation and even more significantly, in her involvement in exploitation of the pampered husband entrusted to her care. In this scenario, the female image seems to be limited to the inessentiality of being that parallels De Beauvoir's depiction in the chapter "Woman's Situation and Character" in The Second Sex; the cultural customs and moral expectations have created a misrepresentation of a woman's right to be treated as equal. Her view on this will shed light on the situation of the male's subjective view of females and the passivity of Behana's character in particular:

"The woman herself recognizes that the universe as a whole is masculine; it is men who have shaped it, ruled it, and who still 


\section{today dominate it; as for her, she does not consider, PhD}

responsible dependent; she has not learned the lessons of violence, she has never emerged as a subject in front of other members of the group. Enclosed in her flesh, in her home, she grasps herself as passive opposite to these human-faced gods who set goals and standards. And in the man's world, since she does not do anything, her thinking as it does not flow into any project, is no different from a dream; she does not have the sense of truth, because she lacks efficacy. She struggles only by means of images and words; that is why she accepts the most contradictory assertions without a problem; she does not care about clarifying the mysteries of a sphere, which in any case is beyond her scope. She settles for horribly vague knowledge when it concerns her; she confuses parties, opinions, places, people, and events; there is a strange jumble in her head" (de Beauvoir 727).

The passivity of female characters, such as Behana and the maid, reduce them into a channel of action for the male characters in the play. Not only do their speech and actions demonstrate passivity and exploitation, but the simple act of being framed as a service proves this to be the purpose behind their characters.

The willingness of the male characters to limit the female's role in pampering the male partner symbolizes the female's otherness and inessentiality. By positioning themselves as de Beauvoir's subject and absolute (26) for whom to be cared and pampered, the female identity becomes de Beauvoir's other. Although viewed as the other, a woman may also collaborate in her submission: "No subject posits itself spontaneously and at once as the inessential from the outset; it is not the Other who, defining itself as Other, defines the One; the Other is posited as Other by the One positing itself as One. But in order for the Other not to turn into the One, the Other has to submit to this foreign point of view" (de Beauvoir 27). Here, de Beauvoir states that there is an element of avoidance at play in this situation in that a woman accepts her status and fails to assert her transcendence, thus rendering her partially to blame for her condition.

Throughout al-Hakim's The Tree Climber, Behana is not only portrayed as being in absolute service to her husband, and the old maid also confirms Behana's status. Even though she hates "domestic work" (al-Hakim 126; act 2), the maid asserts that she works to support her blind husband (al-Hakim 142; act 2). Due to her economic 


\section{From Shakespeare to Modern Ages}

situation, the maid barely tolerates the pain of domestic work but has felt the need and responsibility to support her blind husband. Working as a maid is the only job that a poor woman can have, and this represents how patriarchal Egyptian society was at the beginning of the $20^{\text {th }}$ century. Poor women, such as the maid, suffer greatly due to the double jeopardy of gender and class. The maid is aware of her inferior status and how her life choices are affected by it. When the maid is asked by the milkman to work in the hospital, she boldly replies "No, I don't like working in hospitals...A washerwoman at the Charity Hospital? God forbid! Spend all day washing disgusting clothes contaminated with all sorts of diseases..." (al-Hakim 127; act 2 ). Female involvement in labor work with minimum wages can be seen as a result of the social concentration on securing food without much attention to science and knowledge, and middle-class men and women in Egyptian society at that time were doomed to failure and collapse. A lack of advanced education, social immobility, and blind concentration on the age-old practices of housekeeping and marriage kept these women more or less inferior to men (Le Gassick 91).Thus, it is not surprising to note that the maid is exploited in her work place as a maid and in her own home by being the financial provider.

Even though Bahadir and Behana live under the same roof, they experience the lack of ability to communicate with each other. Each of them has a specific and distinct idea that seems grounded in certain presumptions that limit or sometimes exclude any comprehension of various situations, even when the interpretation of the ultimate facts is concerned. The wife's mind is lost in the illusion of her green dress and of the daughter she never had, while the husband is completely preoccupied with his orange tree that normally bears fruit and the lizard he calls Lady Green, living in a little hole at the foot of the tree. Obviously, Bahadir and Behana are preoccupied with an "intellectual cause" (Zayn al-Din 30). This preoccupation can be seen clearly in the circular dialogue in Act One in which Bahadir and Behana are involved in their first discussion:

WIFE. [turning to where the window is supposed to be]: "Come on, Bahadir! Leave your tree now and come inside! It's chilly outside".

HUSBAND. [he enters carrying gardening tools]: "I know. When it begins to turn chilly the venerable Lady Green goes into her sanctuary. But what I don't understand is that 


\begin{abstract}
Dahlia Kashmiry, PhD
though there is no wind today yet some of oranges are falling. What could have brought them down?"

WIFE. [busy with knitting]: "It was I who brought her down. She was the first fruit and it was I, with my own hand, who aborted her. At that time he didn't want her. It was because poverty; he didn't yet own anything, apart from the small grocery shop. He hadn't yet worked as a commission agent for land in this area, which was waste at that time. He said to me: "Have patience! Don't involve me now in the worry of having children." (al-Hakim 92; act 1)
\end{abstract}

Their conversation is an extreme example of the type of taking at cross purposes in which each relates what the other says to his or her own solipsistic world. Such a lack of communication dominates the whole scene and foreshadows their final failure to communicate with and understand each other and establish a healthy and successful marriage.

This marital failure leads to feelings of directionless and unhappiness, and it is the assertion of de Beauvoir's examination of the marriage institution as "the destiny that society traditionally offers women" (451); thus, Behana is the inheritor of the established structure that society suggests to impose on its people (451). Beauvoir argues that

"Marriage has always been presented in radically different ways for men and for women. The two sexes are necessary for each other, but this necessity has never fostered reciprocity ; women have never constituted a caste establishing exchange and contracts on an equal footing with men. Man is a socially autonomous and complete individual; he is regarded above all as a producer and his existence is justified by the work he provides for the group."(502)

This idea of reciprocity is one of de Beauvoir's most important contributions to existential ethics, and this ethic's only requirement is that each individual recognizes the freedom of the other person with whom he or she has a relationship. She believed it to be essential and writes, "How is it, then, that this reciprocity has not been recognized between the sexes, that one of the contrasting terms is set up as the sole essential, denying any relativity in regard to its correlative and defining the latter as pure otherness?" (27). Behana's lack of reciprocity and her continuous inability to communicate with her husband while her husband is able to communicate with other

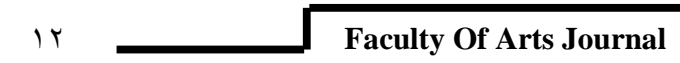


From Shakespeare to Modern Ages

characters in the play indicate the sense of the disharmony in their married life. Also, it reflects the mood of uncertainty and irrationality dominating Behana's and Bahadir's lives. Behana is emblematic of her husband's patriarchal attitudes that have supplanted and denied reciprocity, and his attitudes might be the cause of her three-day disappearance.

Such a lack of communication is so closely interwoven with her lack of mobility and movement that Behana is left with a sense of alienation and depression. For example, the maid confirms that Behana is always in "her green dress, which she never changes, seated in her usual chair" (al-Hakim 92; act 1) and that she goes out "very occasionally, to do some shopping" (al-Hakim 89; act 1), and even the phone is seldom used "since Bahadir Effendi retired. He asked ... since those days I've seldom heard it ring" (al-Hakim 91; act 1). This inability to cross the borders of time and space prevent Behana from occupying a fluid place of her own theoretical and imaginative construction to contest an essentialized view of her identity. The idea that Behana is more bound to the domestic space and to performing domestic duties, while Bahadir is free to advance into the public spheres entailing social interaction captures the destruction of women's lives in a state of loneliness and passivity. In this regard, Bahadir and Behana are and always have been defined as opposing each other biologically and socially.

Behana has a very strong sense of being the other, not only in her current married life with Bahadir, but also with her ex-husband. This sense is reflected her continuous thoughts of Bahiyya, the daughter who was never born. As a young woman of nineteen, Bahiyya acceded to her first husband's request that she have an abortion:

WIFE: [busy with knitting]: "It was I who brought her down.

She was the first fruit and it was I, with my own hand, who aborted her" (al-Hakim 92; act 1).

Behana's painful confirmation that "I, with my hand, who aborted her," powerfully goes with Beauvoir's consideration that a woman seeking an abortion may be "divided against herself," experiencing a "natural tendency to have the baby" and feeling "uneasy about the dubious act she is engaged in" (DiQuinzio 490). Even though Behana's pregnancy was not completed, her pregnancy was experienced with endless enthusiasm. Pregnant Behana happily names the anticipated girl Bahiyya early in the pregnancy as she confirms "in 


\section{Dahlia Kashmiry, PhD}

the early stage of pregnancy I knew the name I'd give her: Bahiyya" (al-Hakim 93; act 1). She further fantasizes about her fetus as she celebrates the physical beauty and health claiming that Bahiyya "would be wonderfully good looking and sturdily built" (al-Hakim 93; act 1).

In gestation, Behana's life appears as a kind of creation, and a completeness of her identity, as de Beauvoir explains:

"The fusion she sought in the arms of the male, and that is refused as soon as it is granted. She is no longer an object subjugated by a subject; nor is she any longer a subject anguished by her freedom, she is this ambivalent reality: life. Her body is finally her own since it is the child's that belongs to her. Society recognizes this possession in her and endows it with a sacred character" (612).

As the pregnancy progresses, Behana feels happy with her fetus. The fetus is her "first fruit" that is firmly settled in her womb, the two organisms are mutually adapted, and between them biological exchanges take place that enable Behana to regain her balance. In particular, clarifies de Beauvoir, she no longer feels herself the prey of the spices, on the contrary, "it is she who possess the fruit of her body" (618). Moreover, as she recognizably becomes a mother to be, her infirmities begin to work to her advantage

"The increasing weakness she suffers from becomes an excuse. Many women then find a marvelous peace in their pregnancy: they feel justified; they always liked to observe themselves, to spy on their bodies; because of their sense of social duty, they did not dare to focus on their body with too much selfindulgence. Now they have the right to; everything they do for their own well-being they also do for the child. They are not required to work or make an effort; they no longer have to pay attention to the rest of the world; the dreams of the future they cherish have meaning for the present moment. They only have to enjoy the moment: they are on vacation. The reason for their existence is there in their womb and gives them a perfect impression of plenitude" (618-619).

Behana's desire to keep her pregnancy "I wish I'd left her to grow" (al-Hakim 93; act 1) becomes undone by her husband's request to obtain abortion, using an economic argument to make Behana grapple with an unplanned pregnancy. He explains to her that he is not financially ready to have a baby since "he didn't yet own anything,

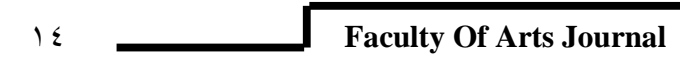


From Shakespeare to Modern Ages

apart from the small grocery shop. He hadn't yet worked as a commission" (al-Hakim 92; act 1).

In a male-dominated society, in which a female, as in Behana's case, is financially dependent upon the male, the male partner constrains a woman's decision about abortion. The decision is literally is taken out of her hands though she is forced to do it by her own hand as she confesses, "It was I who brought her down. She was the first fruit and it was I, with my own hand, who aborted her" (al-Hakim 92; act 1). Behana's experience of abortion reflects the inevitable tension between the account of motherhood and its social meaning in Egypt during the first half of the $20^{\text {th }}$ century. Social context matters here; abortion was first criminalized under the Penal Code on November 13, 1883 in the era of Khedive Tawfiq, which followed in the tracks of the French Penal Code. The criminalization of abortion in Egyptian law was thus inspired by French culture that at the time, was influenced by canon law. Prior to the French revolution, French law considered abortion on a par with murder regardless of when the abortion was carried out. The effect of such a law produced a split in the identity of Behana, a split that forced her to participate in a procedure that is medically dangerous, emotionally damaging, and illegal. In The Second Sex, Beauvoir argues for both legal abortion and freely available contraception, which would "permit woman to freely assume her maternities" without medical necessity that engenders a sense of deficiency that presents as a lack of equilibrium in women.

According to de Beauvoir, "the woman who has recourse to abortion is disowning feminine values, her values, and at the same time, she is in most traditional fashion running counter to the ethics established by men" (DiQuinzio 98). Despite these "ethics established by men," however, men contradict themselves with "careless cynicism," universally forbidding abortion but accepting it when it conveniently solves a problem for them. This double standard can be seen in Behana's ex-husband when he suggests that Behana has an abortion to avoid poverty. At the same time, a "woman feels these contradictions in her wounded flesh" (DiQuinzio 606), especially when abortion is against their freedom with respect to the fact that mothering depends on the control of the body. Thus, Behana's pain stems not only from her own psychological anguish regarding the abortion but from the horrific physical impact to her womb. She asserts the following: "we passed through the days of poverty and when good times came, we sought to have children. But not a bit of it! 


\section{Dahlia Kashmiry, PhD}

Without doubt, it was because the first abortion had affected my womb" (al-Hakim 92; act 1). It is clear that Behana's abortion of the baby girl embodies what male cultural hegemony symbolizes, namely the physical, psychological, and intellectual confinement of the female other. De Beauvoir believes that this confinement of women encourages them to accept mediocrity_instead of greatness, and Behana's acceptance of abortion exemplifies this concept (694).

The depiction of Behana's situation by al-Hakim brings to mind de Beauvoir's thoughts on abortion as a female's choice: "motherhood would be freely chosen; that is, birth control and abortion would be allowed, and in return, all mothers and their children would be given the same rights" (DiQuinzio 856). Behana's flight from the freedom of the self into the object of the other could indeed be described as an example of Beauvoir's bad faith through her subordination to her husband by allowing herself to be ruled by him. De Beauvoir applies "bad faith" to women who opt for the easy, known life, and who flee the possibilities of liberty for the asphyxiating safety of otherness (33). ${ }^{1}$ Her decision to abort does not reflect who she truly is. She strongly embraces the hope that all the problems in her life will be resolved, primarily in the form of living for others, which is a catalyst for her inauthentic living.

Even after all of these years, Behana continues to recall the painful moments of the abortion and still finds herself vaguely bothered by the decision, thus reflecting her inability to cope with her present situation. The inclusion of her age in addition to the endless emphasis on Behana's signs of aging either in the stage direction, "she is about sixty, her hair is white" (al-Hakim 92; act 1), or in the male character's description is never arbitrary because it can provide a strong link to de Beauvoir's question of old age. These perspectives precisely highlight Behana's position in the patriarchal Egyptian society. Throughout the play, male characters, such as the detective and Bahadir, strongly consider aging to be a negative aspect of female identity as indicated when the detective argues that Behana is "a poor old women who's not worth of anything" (al-Hakim 104; act 1). Specifically related to the detective's argument is Bahadir's reflection

\footnotetext{
${ }^{1}$ According to Sartre, bad faith is fostered by a form of self-deception (49). Bad faith starts from people telling a lie to themselves about their identity so as to please others. Bad faith is often trigged by some form of social pressures for an actor to act in ways not ideal to the actor. Human beings are convinced by and deceive themselves that their role in society is who they are (Sartre).

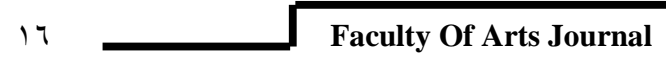


From Shakespeare to Modern Ages

on the implications of Behana's aging, "my wife's sixty and neither of us is any longer physically attractive" (al-Hakim 121, act1), which shows that aging life is composed of the cultural association of ugliness, infertility, and loss. He further asserts that Behana's life is "useless," as he declares "I shall carry her, and I shall bury her under the tree. I regret nothing-her life was useless. Her fruit had fallen, and she lived only in the illusion of being a mother" (al-Hakim 60; act 2 ), pointing out that woman after the fertile years occupies a useless position.

In the chapter. "From Maturity to Old Age," de Beauvoir deals the final blow in her philosophical condemnation of the female condition that highlights Behana's situation: "Entirely dependent, since her adolescence, on her ability to please men, the old woman simply grows more and more powerless. In her situation of dependence, the first hints of bodily decay amount to death itself" (457). In age, this propensity to develop self-deceiving fantasies achieves a further level of absurdity and bad faith. Rather than lying to herself about her future, the old woman now lies to herself about her own past. Thus, Behana finds it difficult to escape her passion and desire regarding her dead daughter, and these feelings lead her to create a private world or personal sphere of material items, such as knitting wool, over which she can assert her sovereignty and into which she can project her tender feelings. Behana's subsequent old age, bad faith, and barrenness have affected her sanity; she has developed a fixation and continues to knit clothes for her unborn daughter: "Her whole mind's on her daughter" (al-Hakim 90; act 1). The maid confirms that obsession for the detective. In doing so, she denies the value of her real life. Old age, according to the same chapter, confirms the emptiness of a woman's life. By taking from them the practical imminent tasks of care and nurturing behind which they have concealed their lack of transcendent purposes, old age forces women to confront their uselessness. De Beauvoir calls this "the pitiful tragedy of the old woman," adding that needlework was invented to conceal her "ghastly idleness" for "knitting and crocheting, the old woman sadly weaves the nothingness of her days" (633).

Al-Hakim skillfully touches on the subject of the old woman that can be linked to El Saadawi's explanation of traditional Egyptian society in which the 
"value of a woman deteriorates with age ... The life of a woman is therefore less than that of a normal human being since it only extends over thirty years. Once she no longer has any menstrual periods, her life is considered over, and she is said to have reached Sin El Ya-as (the age of despair or of no hope)" (83).

In her Learning to be Old: Gender, Culture and Aging, Margaret Cruinkshank supports this idea that ageism is very much related to the cultural concepts attached to the aging of the body. As she states, "learning to be old means fully experiencing the physical, bodily changes that accompany aging while at the same time recognizing that those changes occur in a particular social setting, influenced by our ethnicity, class, gender, political, and economic climate" (1). Actually, Cruickshank compares the situations of old women to those of colonized people, namely, "thought less intelligent, judged solely by appearance, encouraged to imitate the dominant group, figures of fun, scapegoated, [internalizing] messages of inferiority" (4).

What is striking about the inferiority of the female figures is the exposition by al-Hakim of the unpleasant and arrogant nature of two male characters, Bahadir and the Dervish when they agree with each other to make use of Behana's corpse as a "delectable sustenance" (alHakim 160; act 2) to Bahadir's tree. Certainly, Bahadir's assertion that "her whole body should be turned into fertilizer, fertilizer of an excellent quality" (al-Hakim 99; act1) casts much light on his view of Behana as the inferior other. Bahadir strongly believes in the subordination of Behana's entire body, so much so that he focuses on the uselessness of her and tends to use it as a fertilizer. Bahadir's repetition of the word "fertilizer" and his emphasis on her physicality is quite significant in the way it shows how men, such as the detective and Bahadir, expect and believe that every aspect of femininity is about fertility. Intriguingly, through the exposition of Bahadir's behavior, al-Hakim poses a question about the concept of masculine perceptions that connects with de Beauvoir's analysis of why men behave like this. In dominating and judging his wife's life, she argues, a husband makes up for

"All the resentments accumulated daily among other men whose existence means that he is brow-beaten and injured-all that is purged from him at home as he lets loose his authority upon his wife and that when her admiration is not enough, he enacts his power by restoring to tyranny and in this particular case, emotional abuse" (de Beauvoir 566).

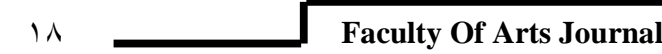


From Shakespeare to Modern Ages

They appear to implicitly embody Mitsein, the concept of themselves as the subject, and the female figure as the other with all its accompanying disavowal of their divine right to be perceived equal in every way (de Beauvoir 29).

In addition to women's exploitation in a consumer society in which a woman's body is treated as an object, a fertilizer, a tool, and a consumable item, violence is obviously directed toward women. In Act Two, the breakdown of communication between Bahadir and Behana takes a new twist. The ensuing confrontation between Bahadir and his wife leads to Behana's tragic end. Bahadir, who is so compelling in his desire to know where Behana has been, admits under pressure that he has previously thought of killing the lizard, the symbol of his wife. The detective, realizing how much more the husband seems to care about his lizard and his tree than about his wife in addition to being struck by the oddness of their conversation, begins to suspect that Bahadir may have killed Behana. When asked if he has ever felt a desire to kill his wife, Bahadir's replay is "Naturally" (alHakim 97; act 1). He arrogantly assumes that any husband must do so sometimes, and he asks the detective to guess where he would have buried her body if he had killed her, adding that the ideal place would be under the tree so that her body would become an excellent fertilizer for the tree. The ensuing conversation increasingly reveals that any murderous intentions were in fact directed against his wife. His philosophizing, hypothesizing, and attention to killing his wife culminate in his rejection of her as the inessential other and her acceptance of him as the absolute subject. When Behana returns home, such philosophical and masculine motives lead him to kill his wife for real at the end of Act Two. He feels no guilt thereafter and decides to risk ultimate arrest and possible execution for the sake of his tree, which can be nourished after burying her corpse underneath it. Bahadir is obviously content in caring for his tree more than his wife, and the detective asserts, "And you love the tree more than her" (al-Hakim 119: act 1). In addition, his clarification that Behana "used not to complain of that" (al-Hakim 119; act 1) confirms de Beauvoir's indication that women are encouraged to accept mediocrity instead of greatness (243).

When Bahadir emerges from prison to find his wife has returned, he insists on knowing where she has been in addition to whether she thought of staying away or not. From this account, the dominating depiction of a masculine subject appears. At first, 


\section{Dahlia Kashmiry, PhD}

Bahadir's determination to discover Behana's whereabouts during her absence is met with refusal to give a definite answer and finally, a string of "no" responses. He names 57 separate kinds of places, asking her one by one whether she was in any of them, and each time she answers "no" without any explanation. As Bahadir's investigations clash with absolute rejections, a moment of masculine tyranny emerges in all of its starkness: "Aren't you going to stop this nonsense? Won't you cease this making fun of me? There's not a man alive who'd stand for it - not one" (al-Hakim 153; act 2). He finally fulfills both his aggression and the Dervish's prediction by surrendering completely to his aggressive instincts to kill her: "[Her] head is seen to drop forward. He shakes her in terror as he sees that she has departed this life" (al-Hakim 153; act 2). In this expression of domestic violence in addition to its portrayal of a man giving way to aggression when confronted with a female's refusal, Bahadir's goal as the male protagonist is to set himself up as an existential "sovereign subject." However, as it is represented in many of these narratives, since this project involves destroying the other that each man is prevented from doing so (Beauvoir 159). In short, what such men seek in patriarchal society is liberation, and thus, the violence to which they resort is imbued with a redemptive quality that becomes tied up in their masculine performances. Acknowledging this association between masculinity and violence, de Beauvoir notes the following:

"Many kinds of masculine behavior spring from a root of possible violence . . . for a man to feel in his fists his will to self-affirmation is enough to reassure him of his sovereignty. Against any insult, any attempt to reduce him to the status of object, the male has recourse to his fists, to exposure of himself to blows; he does not let himself be transcended by others. He is himself at the heart of his subjectivity. Violence is the authentic proof of one's loyalty to himself, to his passions, to his own will; radically to deny this will is to deny oneself any objective truth, it is to wall oneself up in an abstract subjectivity. Anger or revolt that does not get into the muscles remains a figment of the imagination" (343).

By killing his wife, Bahadir exercises his masculine tyranny in addition to the victimization of his wife. Thus, he emphasizes de Beauvoir's idea that females are "the victim of species" (52) and brings this idea to the surface in a male-female relationship.

Indeed, Bahadir seems to have been fundamentally changed by his prison experience, especially when his wife admits that "I still 
From Shakespeare to Modern Ages

don't understand you since your return from prison" (al-Hakim 151; act 2). Bahadir's description that the prison gives "the feeling that you are a fetus which has returned to its mother's womb, the feeding and breathing from within, and waiting for a hand to drag it out at sometime or other" (al-Hakim 141; act 2) presents the feminist and psychological inferiority that exist for women. Bahadir's efforts to explain the prison as a bleak womb may well be interpreted as the symbol of Lacanian symbolic penetration to an untamed feminine space that is found to match his own physical and psychic needs. While necessary to his survival, the prison or the womb is not trusted even after alteration, and that is why he is impatiently waited to escape the feminine space and thus the inferior other. Essentially, the womb metaphor can also be interpreted as an effect to annihilate the symbolic other. For Bahadir, the prison is basically gendered as a female who is limited as a source of feeding, drinking, and sheltering, and when the subject is fully provided, he needs to escape. When he is reunited with this wife, Bahadir is unable to resume his former relationship with her communicating with her in the same obscure way as before; instead, his intellect takes control, and his insistence on a rational answer to his question leads directly to Behana's end. Throughout Behana's tragic death, Bahadir asserts his absolute subjectivity and diminishes Behana's attempts to establish a kind of independence. His violence is prominent evidence of his endless desire to destroy the other for the sake of maintaining his masculinity.

It is remarkable that the portrayal of gender relations in Tawfiq al-Hakim's The Tree Climber is a product of cultural and theoretical influence. The playwright portrays distinctive gender relations in a two-act satirical play designed for and shaped to the ethics of the theatre of the absurd, but the play is actually a perspective of the feminist school, particularly de Beauvoir's theories of otherness, bad faith, and marriage and can be a useful and comprehensive lens through which to understand gender relations in al-Hakim's play. The feminist perspective highlights the challenges of the phallocentric monopoly of the $19^{\text {th }}$-century Egyptian patriarchal society in which women were pushed to the periphery, and the phallus was at the center.

At the start of the play, the playwright depends on rife use of classical Egyptian symbolism, such as the lizard and the cow, to construct female otherness and establish a paradigm of proper wifely behavior in the patriarchal society. The lizard, the symbol of the 
deformed goddess Isis, is used extensively by al-Hakim to represent Behana in and Behana in an attempt to reduce the female's role in providing service, fertility, and protection to the male figure, which is symbolized by the tree. On the other hand, the symbol of the cow in the repeated song, "Oh tree climber bring me a cow with you/Oh cow climber bring me a tree with you" (al-Hakim 109; act 1) can be traced back as far as the ancient Egyptian goddess Hathor, the mother goddess renowned as the patroness of love and fertility. The deep appeal of the cow as a female symbol in the song stems from its absolute service to the male figure, and this service is combined with vacuity, passivity, lack of complexity, complications, and, most importantly, otherness. Beauvoir's The Second Sex stresses the female's situation and detailshow a woman is tagged as other (29) in a patriarchal society, while al-Hakim shows how female characters, such as Behana and the old maid, are viewed in a patriarchal society in addition to how a power structure operates and pursues its pleasure by pushing women to the margin.

Ultimately, such inequality results in unfavorable conditions, such as a lack of communication, which leads to female alienation and marginalization. In this regard, al-Hakim's representation of the malefemale relationship captures the destruction of a woman who lives in a miserable state of loneliness and the existential crisis of life's hopelessness that fulfills de Beauvoir's criteria: "The female, more than the male, is prey to the species" (100). Behana's case clarifies how living alone becomes the bane of existence and conquers people rather than being the conduit of their liberation and freedom. Understanding that man is the essential subject capable of transcendence, mobility, and being a provider, de Beauvoir speaks of woman as the inessential object, a relative other, doomed to immanence: "The individual who is a subject, who is himself, if he has the courageous inclination toward transcendence, endeavors to extend his grasp on the world: he is ambitious, he acts. But an inessential creature is incapable of sensing the absolute at the heart of her subjectivity; a being doomed to immanence cannot find selfrealization in acts" (774).

In addition to Behana's otherness, the essence of her marital decay rests with her experience of abortion, its psychological and physical effects, and the bad faith Behana embraces as her consolation to a dying marriage and ultimately, a dying life. Through the exposition of Behana's crisis of abortion, al-Hakim artfully explores the loss of her natural desire to be a mother. He also reveals how her 
From Shakespeare to Modern Ages

mind has been locked within an illusion centered on her aborted child and how this past event has caused a psychological struggle with the abortion memories. Another basic aspect of al-Hakim's gender relations consists of the strong dependence on the embodiment of bad faith, which is central to de Beauvoir ethics. Behana's acceptance and appreciation of her ex-husband's request for an abortion provide prominent evidence of de Beauvoir's concept of bad faith - that is, she has become a being for others rather than a being for herself. Behana's living for others is ultimately the root of her being for others, and her actions enables bad faith and the males around her to live free. Therefore, the male-female relationship is based on the nothingness of a woman, specifically the old woman, as the logical consequence of a life limited to immanence and the ultimate destiny of the old woman. Bahadir's declaration that Behana's life is "useless" confirms that Beauvoir takes from old women the only quality that one might be tempted to grant them, that is, the wisdom they may have gained from experience thus asserting that this quality is useless in old women: "The wisdom of the old woman remains entirely negative: it amounts to denial, to accusations, to refusal; it is sterile" (637). Subversion becomes a huge expression of the absence of a woman's voice, acknowledgment, or significance in her relationship with the male figure, and it results in excessive violence directed toward her.

Al-Hakim powerfully subverts a predictable ending for gender relations that are reflective of Beauvoir's metaphysics of otherness, bad faith, and freedom. Behana is not free insofar that she is dependent upon all the social constructs that men had created long ago: (1) fertility and (2) marriage. On the other hand, Bahadir shows his freedom (his independence from Behana) and essentially directs his violence against her, thus subjecting her to a tragic death. Her refusal to provide a logical reason for her sudden absence indicates her attempt to resist the patriarchal system and to test the limitations of women's position on the margin of society in order to galvanize a feminist struggle. As Beauvoir noted, unlike other oppressed groups, such as Blacks or Jews, women do not constitute a homogenous group. They have shown no past interest, such as that found in proletarianism (13).

Thus, al-Hakim's representation of gender relations is highly successful theatrically and thematically, and the use of standard literary language in the dialogue contributed to the unreal nature of the play's dramatic logic. Cultural themes and elements of the theatre of 
the absurd are combined to stage female otherness, a female's position in the institution of marriage, the concept of bad faith, the question of old age, and the domestic violence described by the European feminist Simone de Beauvoir. As noted by El Saadawi, al-Hakim often constructs his female characters without the slightest account of religious, intellectual, and/or social values (Abdullahi 165). This assertion is demonstrated in the gender relations in The Tree Climber. To al-Hakim, the women of Egypt are never misrepresented in any form because his sole aim is to educate them on what is fundamentally wrong and right. Tewfik al-Hakim perfectly implemented this with The Tree Climber, which criticizes Egyptian society and points to the absurdity and disillusionment of the modern era.

\section{Results and Findings}

Consequently, Tawfiq Al-Hakim, as an outstanding and one of leaders of Modern Egyptian Drama, creates a new vision of Theatre of Absurd that is dealt with absurdity, seeking the unknown, isolation of individuals and lack of meaning and purpose of life. In his most wellknown play, The Tree Climber is of two great themes that are absurdity of life and oppression and hardships of women. Thus, the study examines oppression of women from their husbands as being dominant of women, as if women are toys or servants to their desires, interests and services. Simone De Beavoir is concerned with theories or ideas of feminist issues. She emphasizes the idea of women otherness, domestic violence, oppression and domination, and these themes are equivalent to Tawfiq Al-Hakim's main ideas in The Tree Climber. Bahana in Al-Hakim's play is portrayed according to notion of women otherness. The play is full of oriental symbols, for instance; the lizard is considered a symbol of old Egyptian goddess Isis. Bahana related to the lizard is also considered a symbol of Isis, pertaining to symbol of protection and a symbol of fertilization. The play is full of Egyptian culture indications and folk doings, for example; Bahadir's song "Oh tree climber bring me a cow with you/Oh cow climber bring me a tree with you, Oh tree climber bring me a cow with you/Milk it and feed me with a china spoon" that is prevalent among Egyptian people and a part of their culture and sense of humor. The theme of absurdity is predominant in the play, as being part of Egyptian society performing any action for granted. 
From Shakespeare to Modern Ages

Works Cited

Abdullahi, Kadir Ayinde. "A Sociological Critique of Gender Violence in Nawal Elsadaawi's Woman at Point Zero." Bassey Andah Journal, vol. 7-8, 2014-2015, p. 156.

Al-Adly, Sabir. "Ya Tali' Al-Shajarah." Al-Funun Al-Sha'biyyah, vol. 56-57, Jul.-Dec. 1997, pp. 41-54.

Bleeker, C.J. Hathor and Thoth: Two Key Figures of the Ancient Egyptian Religion. Brillr, 1973.

Butler, Judith. Gender Trouble: Feminism and the Subversion of Identity. Routledge, 2006.

Cruikshank, Margaret. Learning to Be Old: Gender, Culture, and Aging. Rowman \& Littlefield Publishers, 2003.

De Beauvoir, Simone. The Second Sex. Vintage Books, 1949.

DiQuinzio, Patrice. The Impossibility of Motherhood: Feminism, Individualism, and the Problem of Mothering. Routledge, 1999.

El Sadawi, Nawal. The Hidden Face of Eve: Woman in the Arab World, edited and translated by Sherif Hetata. Zed Books, 2007.

Fonaine, Jean. Death and Resurrection in Tawfiq Alhakim's Literature, translated by Muhamad Guba. alDar alTunisa, 1984.

Davies, Denys Johnson,translator. The Essential Tawfiq Al-Hakim: Plays, Fiction, Autobiography. American University in Cairo Press, 2008.

Hamoudi, Tasediat Ayat. The Influence of the Western Symbolism. Dar Alhadatha, 1986.

Le Gassick, Trevor. Critical Perspectives on Naguib Mahfouz. Three Continents Press, 1991.

Nawal El Saadawi | Egyptian Physician, Psychiatrist, Author and Feminist. Encyclopedia https://www.britannica.com/biography/Nawal-El-Saadawi.

Sartre, Jean-Paul. Being and Nothingness. Routledge, London, 2003.

Smith, Bonnie G. The Oxford Encyclopedia of Women in World History: 4 Volume Set. Oxford University Press, 2008, http://books.google.at/books?id=EFI7tr9XK6EC.

Youkhanna, Nina. Isis: A Play in Two Acts, translated by Nawal ElSaadawi, vol. 1, no. 6. The Word Hord, 2018, https://ir.lib.uwo.ca/wordhoardAvailableat:https://ir.lib.uwo.ca/w ordhoard/vol1/iss6/13.

Zayn al-Din, Nawal. "Al-la-Ma Qul Wa-Al-Zaman Wa-Al-Mutlaq Fi Masrah Tawfiq Al-Hakim, 1998. 